\title{
El testamento de dońa Micaela García. La herencia en un grupo doméstico en Totatiche, Jalisco. 1905-1920
}

\section{Patricia Arias*}

UNIVERSIDAD DE GUADALAJARA

El testamento de doña Micaela García muestra una modalidad de herencia muy particular y diferente a los modelos tradicionales de herencia rural; peculiaridad que tiene que ver, en parte al menos, con las condiciones sociodemográficas y económicas en las que se encontraba la microrregión rural donde ella vivía. El documento testamentario de doña Micaela García permite pensar que en Totatiche se habían construido normas respecto a la herencia que no excluían a las mujeres como sucedía en otras sociedades rurales, como las comunidades indígena y campesina. Los testamentos permiten conocer los recursos materiales de los testadores, en este caso, de un sujeto social diferente a los más estudiados: una mujer. Permite también conocer los marcos normativos acerca de la herencia, confrontar esos marcos con las prácticas, es decir, con las decisiones que tomaron los testadores.

(Herencia, testamento, sociedad ranchera, mujer)

E

121 de mayo de 1907, dońa Micaela García, viuda de 53 años, hizo su testamento. Quizá lo hizo porque se sentía muy mal de la "enfermedad crónica del estómago" que padecía, como quedó consignado en su acta de defunción. Y tenía razón. Menos de un mes más tarde, el 13 de junio de 1907, falleció en El Bajío, rancho que formaba parte de la parroquia de Totatiche, en la región Norte de Jalisco, donde había vivido a partir de su matrimonio. Un día después, el 14 de junio de 1907, se levantó la Manifes-

*mparias1983@gmail.com 
tación de Bienes y Enseres de Casa y se especificaron las hijuelas que recibirían sus hijos.

¿Qué poseía dońa Micaela como para hacer un testamento? ¿Cómo era su grupo doméstico? ¿A quienes dejó como herederos? ¿Qué les heredó a cada quien? ¿Con qué criterios? El testamento de dońa Micaela García ofrece una mirada de primera mano a la herencia, un tema del que se habla y escribe poco, aunque ha sido un asunto crucial en las familias; motivo de tensiones y rupturas que han marcado el destino de muchos descendientes. Como tema de estudio, la herencia ha estado estrechamente ligada al análisis de los testamentos, documento privado e instrumento público por excelencia, que permite conocer los recursos y la voluntad de los testadores.

\section{Sobre LA HERENCIA}

En México, los testamentos han sido explorados por los etnohistoriadores e historiadores desde cinco perspectivas a lo menos: en primer lugar, el rescate, la publicación y el análisis de testamentos indígenas novohispanos de diferentes regiones han permitido identificar las normas, que no los documentos, prehispánicas - más tarde coloniales- de transmisión de la propiedad y el impacto del modelo colonial en las creencias y herencia; el proceso de apropiación de los indígenas de ese tipo de instrumento para ordenar sus asuntos materiales y espirituales; la relación entre preceptos y afectos; entre lo colectivo y lo individual; el valor de las diversas posesiones y el temor al despojo; las especificidades de las regiones; los recursos de pueblos y barrios en diferentes contextos, en especial, en el centro de México; la tenencia de la tierra y las actividades agrícolas; la reconstrucción de genealogías de personas y familias; la reconstrucción de grupos y terminologías de parentesco (Bracamonte y Solís 1996; Carrasco y Monjarás-Ruiz, 1978; Cline y León Portilla 1984; Cline 1986; Kellogg 1995; 2007; Martínez 1984; Rojas Rabiela, Peniche Moreno 2007; Rea López y Medina Lima 1999a y b).

En segundo lugar, y para épocas más recientes - la época colonial y el siglo XIX- los testamentos han ayudado a documentar los recursos económicos - tierras, otras propiedades- y redes de negocios 


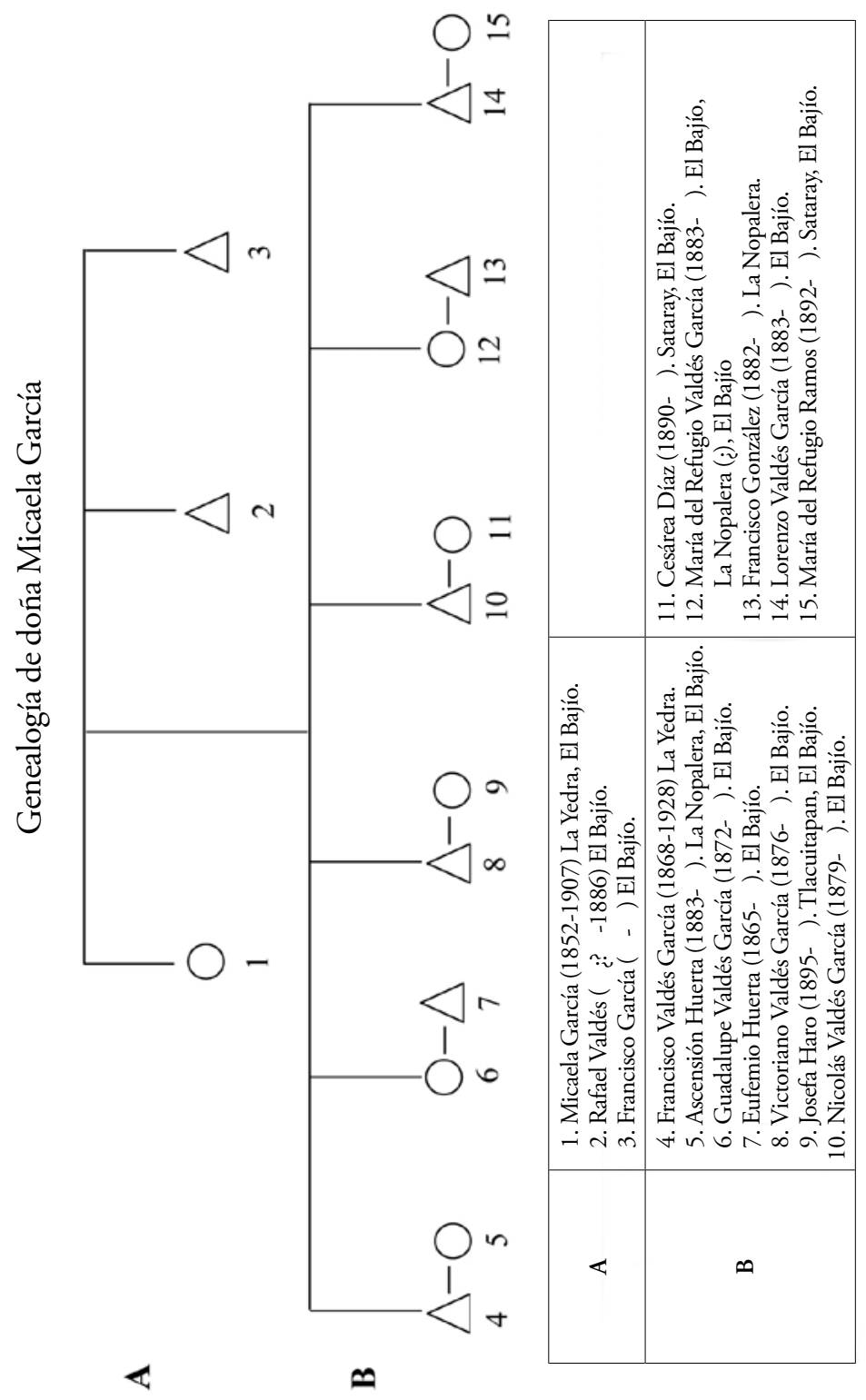


-empresas, acciones-con que contaban personajes importantes del mundo de los negocios en momentos y lugares específicos, lo que ha contribuido al conocimiento de elites regionales o el desarrollo de ciertos sectores de actividad económica (Lizama Silva 2006); en tercer lugar, para conocer con precisión los recursos y disposiciones de personajes políticos y eclesiásticos (Enríquez 1985; Franco 1981; Hillerkuss 2006).

En cuarto lugar, los testamentos contribuyen, como ha señalado Calvo (1989), para el mejor conocimiento de fenómenos sociales, que tanto han preocupado a los historiadores, como el avance del mestizaje o el concubinato en la sociedad novohispana; en quinto lugar, se pueden identificar otros bienes que tenían valor en distinats sociedades y las disposiciones acerca de ellos, como los esclavos, y de esa manera acercarse a las relaciones de sometimiento, justicia, poder que imperaban en la sociedad colonial (Gutiérrez Cham 2003; Peniche Moreno 2007); así como a los impresos que leían, conservaban, heredaban los testadores, lo que permite aproximarse al mundo de la cultura y la difusión del conocimiento (Calvo 1989). En general, se trata de testamentos masculinos de personas que vivían en las principales ciudades y formaban parte de las elites coloniales o decimonónicas.

Debido sin duda al creciente interés por los estudios de la mujer, lo femenino y la perspectiva de género, se ha comenzado a buscar y procesar información que dé cuenta de la relación entre la herencia y las mujeres. Esta preocupación se ha desglosado en dos grandes interrogantes: por una parte, si las mujeres, en diferentes momentos históricos y distintas sociedades, han sido sujetos de herencia y, por otra, en caso de que lo fuesen, cómo ellas, a su vez, han heredado sus bienes.

Los resultados han sido sorprendentes. Kellogg (1995), con base en 23 testamentos de los siglos XVI y XVII, encuentra que el sistema de herencia indígena era bilateral, es decir, que las mujeres podían ser herederas de tierras, mediante herencia o dote. Y eso no era venial. Los bienes más preciados eran la tierra, la casa y los muebles (Kellogg 1995). Pero la información le sugiere también que las mujeres habían empezado a estar en desventaja como herederas de la tierra. 
Pero además, descubre que a lo largo del siglo xvi, hubo cambios significativos, entre 1546 y 1581 había muchos herederos posibles: hijos, pero también sobrinos, nietos y bisnietos; las mujeres preferían heredar a mujeres tanto casas como muebles y dejaban menos herencia a los esposos. Pero más tarde, entre 1581 y 1649, se restringe el rango de los herederos posibles a las relaciones nucleares y lineales, se percibe un cierto empobrecimiento de la población y se constatan tensiones en las relaciones conyugales y familiares (Kellogg 1995). Hay indicios también de que las mujeres, vía el mercado, estaban teniendo acceso a mayores montos de dinero, ropa y otros objetos; algo que también ha encontrado Cline (2007). Kellogg advierte un hecho importante: los españoles estaban mucho más preocupados que los indígenas por evitar la fragmentación de la propiedad y, para lograrlo, preferían la figura del heredero único universal (Kellogg 1995).

Cline (2007) encontró situaciones muy similares en Culhuacán, donde las mujeres tenían tierras, incluso, muchas tierras. Ella lo atribuye a dos posibles razones: por una parte, que se trataba de mujeres de la elite, que ya tenían tierras desde la época prehispánica o, bien, a que debido a las epidemias que tanto asolaban a las poblaciones, los hombres prefirieran dejar como herederas a las mujeres. Respecto a si ellas preferían dejar a otras mujeres como herederas, existe gran ambigüedad. Cline encuentra mujeres, nunca hombres, que dejaron todo a la Iglesia, y advierte también que las mujeres eran herederas residuales, más a menudo que los hombres (2007).

En contraste, Peniche Moreno, ha señalado que en Yucatán, en los siglos XVIII y XIX, al menos, se trataba de un sistema de herencia patrilineal con "algunos rasgos de primogenitura" $(2007,249)$. Es decir, una situación similar a la encontrada en la sociedad mesoamericana (Robichaux 2007).

Por su parte, Teresa Rojas Rabiela, Elsa Leticia Rea López y Constantino Medina Lima (1999b) recopilaron testamentos novohispanos del siglo Xvi encontrados sobre todo en el Archivo General de la Nación. De los 40 testamentos reunidos, 11 corresponden a mujeres y uno más se refiere a una donación, también de una mujer. A pesar de que se trata de pocos documentos, llaman la atención tres situa- 
ciones. En primer lugar, que ellas - enfermas, pero lúcidas- habían querido hacer los testamentos; en segundo lugar, la enorme variedad de situaciones étnico-sociales (noble, principal, india, natural) y sociodemográficas de las testadoras (solteras, viudas, casadas). En tercer lugar, lo más notable es que a través de esos testamentos se sabe que ellas habían sido herederas por parte de sus padres y madres y, a su vez, eran testadoras que ejercían sus derechos, al parecer, con bastante libertad. Una de esas libertades era sin duda que tomaban muy en cuenta a sus propias hijas como herederas de casas y tierras.

Tonella Trelles (2001), por su parte, analizó 96 testamentos muchos más tardíos, otorgados en la población de Ures, Sonora, entre 1862 y 1902 . De ellos, 22 son testamentos de mujeres que fueron otorgados entre 1881 y 1902. Más de la mitad de las testadoras eran viudas: $52 \%$. La autora muestra que en esa localidad, en ese tiempo, había mujeres que contaban con recursos propios y heredados, que a su vez heredaban con bastante libertad. Predominaba, dice, la herencia igualitaria a herederos directos, sin distinción de sexo. Aunque, en uno de los casos que documenta, la madre había preferido al hijo primogénito (Tonella Trelles, 2001).

La existencia y el contenido de los testamentos históricos contrastan con la información etnográfica posterior acerca de la herencia en las sociedades mesoamericanas. En general, en las comunidades indígenas y campesinas tradicionalmente estudiadas por los antropólogos, no había -o en todo caso no se buscaban- documentos escritos acerca de la herencia. Quizás, porque se constataba la existencia de vigorosos mecanismos consuetudinarios, comunitarios y familiares, no formales de transmisión de los recursos de una generación a la siguiente. Por una parte, estaban las normas sociales e instituciones, como el ejido, que garantizaban el acceso a la tierra y los recursos colectivos a las sucesivas generaciones de miembros de las comunidades, en especial, a los hombres (Deere y León 2002). El reparto agrario, que asoció la dotación de la parcela ejidal a la noción de proveedor masculino, reforzó la herencia de la tierra con predominio masculino y patrilineal.

En el siglo xx, el modelo de reproducción social mesoamericano, compartido por la mayor parte de las sociedades indígenas y campe- 
sinas, pautaba quienes eran los herederos deseables de los recursos privados de los hogares, en especial, de la casa. De acuerdo con Robichaux (2007) en las sociedades mesoamericanas, la dinámica familiar -y la herencia- estaban modeladas por tres principios culturales: residencia patrivirilocal, herencia igualitaria de la tierra con privilegio patrilineal y herencia de la casa por ultimogenitura masculina. En ese contexto, el hijo menor -el xocoyote- era el que heredaba la casa de los padres y era el que se encargaba de atenderlos hasta su muerte (Robichaux 2007).

Quizá la evolución del modelo mesoamericano había llevado a que la herencia más incierta fuera la de las mujeres. De acuerdo a la norma residencial patrivirilocal, ellas, al momento de la unión, pasaban a residir en la casa de los suegros. Al salir de sus grupos domésticos las mujeres dejaban atrás también la posibilidad de ser herederas en sus familias, pero también en las de sus cónyuges. De acuerdo al principio patrivirilocal, los hombres trabajaban, recibían recursos y herencia que, a su vez, heredaban a sus hijos. De esa manera, ellas no eran sujetos de herencia ni heredaban a sus descendientes.

Las mujeres eran, como bien lo ha señalado González Montes (2002), "herederas residuales" a las que se les adjudicaba la propiedad de una parcela ejidal sólo cuando los padres carecían de herederos varones, cuando los titulares habían tenido que salir de la comunidad, cuando enviudaban con hijos pequeños, en tanto estos crecían y podían hacerse cargo de la tierra.

A partir de la microhistoria de San José de Gracia (González 1979) se comenzó a conocer otra historia de la gente del campo, menos extendida y generalizada que la de las sociedades indígena y campesina, que prosperó en algunos ámbitos de las tierras altas de los estados de Guanajuato, Jalisco, Michoacán: la sociedad ranchera, que en su proceso de construcción acunó una serie de peculiaridades (González 1989). Una de ellas, parecería ser que las mujeres recibieran herencia -casas y ranchos- en mayor medida que en las sociedades de tradición mesoamericana (Arias 2005). Sin embargo, esa información ha surgido de materiales etnográficos, no documentales. 
Así las cosas, el testamento de doña Micaela muestra, dentro de una sociedad ranchera, una modalidad de herencia muy particular $y$ diferente a uno y otro de los modelos mencionados, que tiene que ver, en parte al menos, con las condiciones sociodemográficas y económicas en las que se encontraba la microrregión desde mediados del siglo XIX. Permite conocer también los diferentes tipos de bienes que la gente tenía y valoraba, tanto como para mencionarlos en su última voluntad, en esa sociedad, en ese tiempo.

La trayectoria y características de la parroquia de Totatiche, donde vivía dońa Micaela García, corresponden a las de las sociedades rancheras, aunque esa microrregión parece haber sido mucho más pobre y aislada que los ejemplos hasta ahora conocidos. En términos geográficos, la parroquia estaba ubicada en tierras altas y flacas de la región Norte de Jalisco; en términos espaciales, se trataba de una sociedad rural que vivía muy alejada y aislada, donde la gente salía poco y llegaba poco; en términos económicos, los grupos domésticos vivían de una agricultura de subsistencia, pero sobre todo, de la actividad ganadera, del jornalerismo y la mediería; en términos culturales, se trataba de una sociedad mestizada, embebida de una religiosidad católica muy profunda y arraigada, donde el núcleo social básico eran grupos domésticos, por lo regular emparentados, que se unían en ranchos de diferente tamaño (Arias 2014).

De ese mundo era dońa Micaela García y su testamento puede servir de botón de muestra de la situación de las mujeres en una parroquia rural de carácter ranchero a principios del siglo xx. No de todas las mujeres desde luego. Dońa Micaela pertenecía al reducido grupo de propietarios.

Así las cosas, puede decirse que los testamentos e inventarios permiten conocer los recursos materiales de los testadores, en este caso, de un sujeto social diferente a los más estudiados: una mujer. Permite también conocer los marcos normativos acerca de la herencia, confrontar esos marcos con las prácticas, es decir, con las decisiones que tomaron los testadores. En los testamentos dialogan y se ajustan los modelos y las normas sociales con los afectos y consideraciones acerca de los descendientes. 
En el caso de doña Micaela, la posibilidad de combinar el testamento, la manifestación de bienes y las hijuelas, con información sociodemográfica en dos momentos, ha permitido conocer además las características y dinámica de su grupo doméstico y la organización social de esa sociedad ranchera a principios de siglo Xx.

\section{LAS FUENTES}

Este artículo se basa, en primer lugar, en el Testamento, la Manifestación de Bienes y las Hijuelas de los hijos de doña Micaela García; documento que se encuentra en el Archivo del Arzobispado de Guadalajara (AHAG, Gobierno, 1907). Se trata de un documento de 11 páginas que ha sido procesado para los ejercicios que se presentan a continuación. Se basa también en la información de los Padrones de población de la parroquia de 1905 y 1920 que se resguardan en la Notaría Parroquial de Totatiche. Ambos padrones ofrecen información que hoy llamamos sociodemográfica y espacial sobre los vecinos de cada uno de los lugares habitados en esos dos momentos.

El Padrón de 1905 está contenido en un cuaderno de tamaño oficio empastado de 155 páginas numeradas que contiene, en diferentes columnas, la siguiente información: número correlativo de personas, nombre de cada persona con un apellido, edad, estado civil, lugar de origen, lugar de residencia y profesión. El Padrón de 1920 fue levantado en mayo de ese ańo por el sacerdote, hoy santo, el padre Cristóbal Magallanes. Contiene la siguiente información: número correlativo, nombre de cada persona con un apellido, domicilio (nombre de la localidad), sexo, edad, estado civil y profesión. Los padrones resultan comparables porque ambos ofrecen información acerca del nombre y apellido de las personas, sexo, edad, estado civil, lugar de residencia y la actividad a la que se dedicaban los vecinos. Se utilizó también la información de los libros de matrimonios y defunciones entre los años 1900 y 1920 en el caso de las defunciones y de 1900-1919 en el caso de los matrimonios; documentos que se encuentran también en la Notaría Parroquial de Totatiche. La información de los padrones y libros fue fotografiada y, más tarde, en Guadalajara, convertida en bases de datos. 
En ambos padrones aparece el grupo doméstico de dońa Micaela García, lo que nos permitió comparar su composición en esos dos momentos que corresponden a la situación antes y después de que muriera doña Micaela. Finalmente, recurrimos a los documentos familiares y entrevistas con don Ángel Pinedo Valdés, bisnieto de doña Micaela; además de otros vecinos de Totatiche, en Totatiche y en la ciudad de Guadalajara.

\section{La PaRroquia de Totatiche en i905}

De acuerdo con el padrón de 1905, la población de la parroquia de Totatiche sumaba 10,520 almas. El pueblo de Totatiche, que era también la cabecera municipal, era el centro de las actividades políticas, religiosas, de servicio y comerciales del municipio. Allí se celebraban los oficios religiosos -la misa de "precepto" cada ocho días-y era el lugar donde acudían, cada semana, muchos de los vecinos de la parroquia, además de los que necesitaban registrar a los recién nacidos, a celebrar bodas, despedir o registrar difuntos, hacer trámites (AHAG, Gobierno, 1895-1906). Pero sólo una décima parte de la población de la parroquia vivía en la cabecera: 823 almas.

Porque la mayor parte de la población residía y trabajaba en ranchos de diferente tamaño, aunque más de la mitad de la población se ubicaba en asentamientos de menos de 200 habitantes. Se trataba de asentamientos que reunían entre 10 y 39 grupos domésticos. En general, los hogares en Totatiche eran pequeños -3.5 miembros- $y$ el principal tipo de hogar era el nuclear, es decir, el que estaba conformado por una pareja y sus hijos (Arias 2014).

Según recuerdan los vecinos sobre la situación de sus antepasados, la principal forma de trabajo era la mediería. En la parroquia había mucha, muchísima gente que no tenía tierras. Por esa razón, la mediería era la manera de organizar la producción de parte de los que tenían propiedades más extensas que no podían o querían trabajarlas de manera directa. Un ranchero con abundante tierra podía llegar a tener entre seis y doce medieros cada temporada.

¿Qué era un rancho? En Totatiche la noción de rancho alude a dos situaciones diferentes: por una parte, se refiere a un lugar po- 
blado donde vivían un número variable de grupos domésticos, muchos de ellos emparentados. Pero alude también al lugar y la forma de vida y trabajo de cada grupo doméstico. En ese sentido, cada casa era también un rancho que incluía la casa, el corral donde estaban los animales (gallinas, puercos, vacas, caballo, burro, yegua), todo cercado. Más allá estaba la zona de siembra, a la que llamaban "barbecho", que era donde se sembraba. Y así sucesivamente, un rancho seguía al otro. Un arroyo solía dividir dos ranchos de diferente nombre.

En 1905 y en 1920, la principal actividad económica de los vecinos eran la cría de ganado y la agricultura. La parroquia recibía sus diezmos y primicias en cereales, pero estaba al pendiente y tomaba muy en cuenta la cantidad de animales que tenían los fieles para calcular los gravámenes que le correspondían. En julio de 1905, el señor cura de Monte Escobedo, Zacatecas, solicitó la intervención del Arzobispo de Guadalajara porque "algunos de mis feligreses tienen crías de ganado en territorio de ese arzobispado y por la distancia de la colecturía de diezmos se disimulan en sus pagos", por lo que le solicitaba "me facultara el Hacedor de esa para cobrar a estos mis feligreses lo que deban y debieren en lo sucesivo" (AHAG, Gobierno, 1905).

¿Qué tenía valor en esa sociedad? Desde luego, los ranchos donde cultivar la tierra y agostar el ganado. Lo que valorizaba un rancho era que tuviera aguajes, accesos y, sobre todo, la demanda, es decir, que algún vecino quisiera y estuviera en condiciones de ampliar su propiedad, como parece que fue el caso de la venta del rancho de doña Micaela.

Todos los ranchos de la parroquia eran de propiedad privada. La única excepción que se recuerda era Azqueltán, la comunidad indígena muy alejada de la cabecera, donde predominaba la propiedad comunal de las tierras. En general, aunque no hubiera documentos ni escrituras que avalaran las propiedades y las transacciones de los ranchos, estas últimas eran muy comunes. Los continuos altibajos económicos afectaban de manera inmediata los recursos de los grupos domésticos por lo que había cambios frecuentes de propiedades -o partes de propiedades-al interior de los ranchos, entre vecinos y familiares. Los límites de los ranchos se 
marcaban con piedras que actuaban como mojoneras que la mayoría de la población reconocía y respetaba.

El ganado, las distintas especies de animales, eran fundamentales para las diferentes actividades agropecuarias. Los vecinos recuerdan que sus antepasados requerían de yuntas de bueyes para labrar la tierra; de caballos para las tareas del rancho porque éstos se encargaban de la carga así como de cuidar el ganado, además de ser el principal medio de transporte de hombres y mujeres. Los burros servían para acarrear las cosechas. Las mulas y machos se utilizaban también para carga, pero para distancias mayores, por ejemplo, para ir a Aguascalientes, Guadalajara o Zacatecas.

Las vacas y toros, que eran lo más preciado y lo que todo grupo doméstico procuraba tener, eran para cría y para leche, que se utilizaba para el consumo y para elaborar diferentes productos lácteos. La mayor riqueza de un ranchero era tener muchas vacas de "pial", es decir, de ordeña, por la leche y por la posibilidad de vender las crías. La producción de leche se destinaba a la fabricación de quesos, crema y jocoque, que era la base de la dieta, y su manufactura era una actividad básicamente doméstica, para consumo familiar. Hasta los más pobres procuraban tener una o dos vacas para la alimentación de su grupo doméstico.

La imagen que queda del Padrón de 1905 es de que en la parroquia, aunque predominaba un poblamiento muy disperso, se trataba de un territorio habitado por múltiples ranchos de diferente tamaño. Los ranchos, donde coexistían la residencia y la actividad económica, trabajados de manera independiente o por trabajadores, habían hecho que los vecinos aprendieran a vivir, convivir y trabajar bastante aislados y en agrupamientos de pocas familias.

\section{El Bajío en 1905}

El Bajío fue nombrado por primera vez como rancho en 1885 (Bárcena 1983) y apareció en los Padrones de 1905 y 1920 como Bajío de Sánchez; al parecer se referían a él también como Bajío de la Cruz (Arias 2014). Se ubicaba a ocho kilómetros al oeste de la cabecera municipal de Totatiche. En 1905 allí vivían 209 personas, de las 
cuales 90 eran mujeres y 119 hombres. La mayoría de los habitantes -84.2 \%- había nacido ahí mismo. Había 33 personas que habían nacido fuera, la mayor parte, en poblaciones cercanas a El Bajío. El principal mecanismo por el que habían ingresado personas, en especial mujeres, era el matrimonio. De las 33 personas nacidas fuera, 14 eran mujeres que, al casarse con vecinos de esa localidad, se habían trasladado a El Bajío, donde vivían con sus esposos, donde nacían y criaban a sus hijos, donde seguramente morirían.

En 1905 en El Bajío había 46 hogares. La mayor parte -17- eran hogares nucleares; pero había 8 hogares integrados por viudas con hijos. Ese era el segundo tipo de hogar más frecuente en El Bajío.

\section{Doña Micaela García en i 905}

Uno de esos 8 hogares formados por una madre viuda era el de doña Micaela García, que en 1905 vivía con cuatro hijos solteros, tres hombres y una mujer: Victoriano, Nicolás, Lorenzo y María del Refugio Valdés García. En ese momento, ella dijo tener 53 años, es decir, que había nacido a mediados del siglo XIX, quizá en 1852 .

La familia de doña Micaela era originaria de Valparaíso, Zacatecas, de donde se había movido, hacía muchos años al rancho Conformidad, más tarde a La Yedra, ambos ubicados al norte de El Bajío y también formaban parte de la parroquia de Totatiche (Pinedo Valdés, s.f.). A la familia García se le identificaba con La Yedra, que era donde habían comprado un rancho y tenían la "casa grande" dice don Ángel Pinedo, su bisnieto (en lo sucesivo A.P., comunicación personal).

Doña Micaela se casó con don Rafael Valdés, originario de El Bajío; rancho que se identificaba como tierra de los Valdés. Es probable que al casarse ella haya migrado de La Yedra a El Bajío, como se acostumbraba en el caso de las mujeres al momento del matrimonio. Parecería que ella se casó a los 15 ańos y tuvo a su primer hijo, Francisco, a los 16 años que nació en el rancho La Yedra (A.P., comunicación personal).

Doña Micaela enviudó en 1886, es decir, cuando tendría 34 años. Su esposo, don Rafael, habría muerto joven (A.P., comunicación per- 
sonal). En sus 18 años de matrimonio procreó 11 hijos, de los cuales sólo 6 sobrevivieron: 4 hombres y 2 mujeres. Desde su viudez, su hijo mayor, Francisco, de 18 ańos, se hizo cargo de sacar adelante las actividades económicas y se convirtió en el jefe de hogar de facto al que sus hermanos obedecían y respetaban (Pinedo Valdés, s.f.).

En 1905, vivían en El Bajío: Francisco, de 37 años; Guadalupe, de 33; Victoriano, de 29; Nicolás, de 26; María del Refugio y Lorenzo, de 22 años. Estos dos últimos eran, quizás, cuates o gemelos, algo bastante recurrente en Totatiche. En ese momento, los dos hijos mayores, Francisco y Guadalupe, ya estaban casados y vivían en el mismo rancho, al parecer, muy cerca de la casa de su madre. Francisco, que era labrador, se había casado, en 1899, cuando tenía 36 años, con Ascensión Huerta, de 22 años, con la cual acababa de tener un hijo: Ángel, de apenas un día (o 3 años, A.P. comunicación personal). Ascensión era originaria del rancho de La Nopalera, de la misma parroquia. La boda civil se celebró en El Salitre y la religiosa en el templo de Totatiche (Pinedo Valdés, s.f.). Francisco era en ese momento administrador de la llamada hacienda de Conejos (Pinedo Valdés, s.f.).

Guadalupe, hermana de Francisco, se había casado muchos años antes, alrededor de 1892, a los 20 años, con Eufemio Huerta, labrador de 27 años, quizá pariente de Ascensión Huerta, pero en cualquier caso, vecino de El Bajío. En 1905, el matrimonio de Guadalupe y Eufemio tenía cuatro hijos: Jorge, de 12 años; Hildefonso de 9; Rafael, de 8 y Aleja de 7. Al parecer, no tuvieron más hijos, vivos al menos y, poco después, a los 34 o 35 ańos, Guadalupe enviudó.

Doña Micaela, como sus dos hijas, no sabía firmar, pero fue de las pocas mujeres -18-que en el Padrón de 1905 aparecieron como labradoras, lo que significaba que se dedicaban a la agricultura, en su caso, como propietaria de un rancho. Con dońa Micaela trabajaban sus hijos Victoriano y Nicolás, que también declararon ser labradores. Lorenzo, el menor, no declaró oficio ni tampoco María del Refugio.

Entre 1905 y 1907, hubo algunos cambios en el grupo doméstico: su hija Guadalupe enviudó y tres de sus hijos -Victoriano, Lo- 
renzo y María del Refugio- se casaron. Victoriano, de 30 años, se casó con Josefa Haro, de 20 ańos. Ella era originaria de Tlacuitapan, localidad pequeña de la parroquia donde vivían 94 personas. Lorenzo, de 24 años, se casó con María del Refugio Ramos, de 14 años, originaria de Sataray, otra localidad pequeña de Totatiche, donde vivían 50 personas.

María del Refugio se casó a los 22 años, con Francisco González, de 23 años, originario y vecino de La Nopalera. No sabemos con certeza si María del Refugio se fue a vivir a La Nopalera, también localidad de Totatiche donde vivían 169 personas. Pero es muy probable que haya sido así, ya que la norma era que al casarse las mujeres se trasladaran al lugar de residencia de los maridos. La residencia patrilocal postmarital era la norma en la microrregión. Pero años después, María del Refugio, en calidad de viuda, apareció de nueva cuenta como vecina de El Bajío. Eso ratificaría la impresión de que las mujeres, cuando enviudaban, podían y solían regresar a su comunidad de origen.

¿Dónde y cómo vivía dońa Micaela? En su testamento dijo que su casa "de mi morada [estaba] compuesta de cuatro piezas de terrado, dos jacales techo de zacate y corrales y magueyes que la rodean". Dijo también que era propietaria de un rancho de "labor y erial de media caballería poco más o menos $[$ sic $]$ que era de su propiedad". La casa formaba parte del rancho. No mencionó que se tratara de una propiedad que hubiera heredado de su marido.

Doña Micaela era de las personas o familias que tenían más recursos en el Bajío. Desde luego, no era de los grupos domésticos que carecían de tierras y vivían de establecer contratos de mediería con los labradores o de vender su fuerza de trabajo como jornaleros.

\section{El testamento de doña Micaela García. I907}

Cuando doña Micaela murió, en 1907, sólo vivía con ella su hijo menor, Nicolás, soltero de 28 años y en la herencia hubo algún sesgo a favor suyo, pero sólo en lo que toca a la casa y enseres. Además de la parte correspondiente del rancho y la hijuela dońa Micaela le dejó por donación 
la sala de mi habitación, la cocina de terrado que está pegada y al norte de la expresada sala con todo y todo y el corral de patio con todo y unos ocho metros de cerca más o menos que lo dividen; una imagen del Señor San Cayetano que es de mi propiedad con una sala que circula el mismo patio antes dicho y más avíos y adornos que son propios del Señor San Cayetano con todo y sala últimamente mencionada, todo dejo a mi mismo hijo Nicolás.

Lo donado a Nicolás fue lo único que quedó estipulado directamente en el testamento y a lo que doña Micaela no le asignó un valor monetario.

Pero no se trató de un regalo incondicional. Doña Micaela dejó dicho de que "en caso de que "mi expresado hijo se muera, se ausente o haga poco aprecio de la Imagen e interés de la misma, dispongo que entre todos mis demás hijos e hijas se eche en suerte y el que lo saque sea dueńo de ella con todo lo que se reconozca propio de la citada Imagen para que cuide de ella y lo de ella”.

En la casa guardaba "veinticinco hectólitros de maíz" que estipuló que se vendieran para pagar su entierro - “cajón y demás”-, así como para que se mandaran "decir las misas de San Gregorio por el bien de mi alma y que mi cuerpo sea sepultado en el campo mortorio $[s i c]$ de Totatiche". Al parecer, en eso no le hicieron caso porque la enterraron en el camposanto de Juanacatic, más cercano al Bajío; pero sí realizaron el registro correspondiente en la parroquia de Totatiche.

Doña Micaela afirmó que a nadie le debía nada y que más bien dos personas: don Luciano García y don Lino de la Rosa, le debían dos pesos cada uno. Ambos deudores vivían en el pueblo de Azqueltán, el asentamiento indígena de la parroquia. Del resto de sus bienes, dijo "mande se reparta con igualdad partes iguales [sic] entre todos mis seis hijos e hijas", decisión que ella ya les había comunicado y con la cual todos estaban de acuerdo. Pero al parecer no fue así. Don Francisco, el hijo mayor, consideró que "se notaba que a unos favorecía más que a otros" y le "observó que esa repartición no era justa y que él no estaba de acuerdo, pero que ese asunto se lo expusiera al Señor Cura. Que si el Señor Cura estaba de acuerdo, que él 
también estaría de acuerdo, pero que si el Señor Cura no estaba de acuerdo, que tampoco él sería de acuerdo" (Pinedo Valdés, s.f., 15).

No se sabe si hubo ese encuentro entre dońa Micaela y el sacerdote ¿Don Francisco esperaba una proporción mayor de la herencia en virtud de su dedicación de tantos años al hogar de su madre y hermanos cuando ella enviudó? ¿Tanto que pospuso su matrimonio hasta cumplidos los 36 ańos, cuando sus hermanos ya habían crecido y pudieron relevarlo de ese compromiso? Si fue así, doña Micaela no aceptó sugerencia alguna al respecto. Ella heredó a sus seis hijos por igual, independientemente del género, edad y condición en que se encontraban al momento de testar.

En el testamento quedó estipulado que los hijos e hijas de doña Micaela, aunque fueran "vendedores casados no necesitan el consentimiento de sus respectivos cónyuges por haber adquirido por herencia el terreno motivo de la operación”. Eso avala la idea de que las mujeres podían recibir bienes y a su vez heredarlos con libertad para disponer de ellos.

El bien que tenía más valor era el rancho "de labor y agostadero", con "una extensión superficial de diez y siete hectáreas, sesenta y cuatro aras [sic] y sesenta y dos centiaras" que, siete meses más tarde, el 24 de diciembre de 1907, sus hijos vendieron a Francisco García en $\$ 200.00$. El rancho de dońa Micaela colindaba con otras propiedades de Francisco García y de sus hijos Francisco, Victoriano y Lorenzo Valdés García.

El consenso, el acuerdo, pero también el parentesco entre las partes resultaban cruciales debido a que, en muchos casos, como el de dońa Micaela, no existían títulos de propiedad: la transacción se hizo "no entregando ningún documento por no haberlos" [...] "el adquirente aceptó esta escritura en todas sus partes dándose por recibido del terreno a su satisfacción". El comprador del rancho, Francisco García, de sesenta años, era hermano y vecino de doña Micaela (A.P., comunicación personal). La persona que firmó los documentos a nombre de doña Micaela fue Pablo García, al parecer, otro hermano de doña Micaela, viudo de 66 años que vivía en La Yedra.

El comprador del rancho, Francisco García, también labrador, estaba casado con Refugio Valdés, de 47 años, vecina, que quizá 
también era pariente de los hijos de doña Micaela por parte de su padre. Parecería que el hogar de Francisco era de segunda unión. Con él y su esposa sólo vivía un hijo de ambos: José García, de 17 años, soltero. Muy cerca, pero aparte, vivía Pablo García, al parecer otro hijo de don Francisco, de 35 años, que estaba casado con Francisca Ávila. Quizá otros hijos e hijas de Francisco, del primer matrimonio, habían salido ya del hogar, algo muy usual en la parroquia. De cualquier manera, el rancho de doña Micaela se sumó a las propiedades que ya tenía Francisco García en El Bajío. Los Valdés y los García tenían una serie de propiedades muy próximas en El Bajío.

De los ciento veintidós rubros de las otras posesiones de dońa Micaela, veintinueve correspondían a animales y seis a aperos relacionados con los animales que en total tenían un valor de $\$ 78.00$ (cuadro 1). El valor de los animales queda muy claro en el testamento de dońa Micaela, tanto por el precio que tienen como por la minuciosidad con que se describen sus características y condiciones. Ella declaró tener como bienes varios semovientes: una yunta de bueyes; cinco vacas horras "contando en estas una baquilla [sic] cargada; cinco becerros y becerras de un año unos otros de dos; un caballo de silla o manso; cuatro burras aparejadas; dos burras chicas". Los animales eran el segundo activo de más valor de los bienes de la difunta.

En el inventario se especificó con todo detalle, el sexo, color y valor de bueyes, vacas, toretes, becerros, burras, puercos y puercas (cuadro 1). Los dos bueyes formaban parte de una yunta para las tareas agrícolas. En la región Norte, la yunta de bueyes era crucial para cualquier economía familiar ya que era el instrumento básico, único en realidad, para trabajar la tierra (Muriá 1980, tomo 3).

El precio de los animales variaba de acuerdo a su especie y condición. El de mayor precio era el ganado vacuno - bueyes, vacas, becerros, toretes-, seguidos de los burros y, en último lugar, los puercos. Valían más los animales si estaban cargados (cuadro 1). La existencia de burras y puercas indica que el grupo doméstico producía y reproducía animales de distintas especies que les servían para llevar a cabo el transporte, los quehaceres agrícola-ganaderos así como para la venta $y$, en menor medida, la alimentación. Aunque se señalaba la 
Cuadro i. Animales y Aperos

Micaela García

\begin{tabular}{|c|c|c|c|}
\hline \multicolumn{4}{|c|}{1907} \\
\hline Núm. & Animales & Descripción & Valor \\
\hline 1 & Buey & grande pinto de negro & $\$ 10.00$ \\
\hline 2 & Buey & grande pinto de hosco & $\$ 1.00$ \\
\hline 3 & Vaca & horra o cargada & $\$ 7.00$ \\
\hline 4 & Vaca & horra o cargada & $\$ 7.00$ \\
\hline 5 & Vaca & zorrilla & $\$ 7.00$ \\
\hline 6 & Vaquilla & gruperilla & $\$ 7.00$ \\
\hline 7 & Vaca & chueca de añejo & $\$ 6.00$ \\
\hline 8 & Torete & de dos ańos, barroso amarillo & $\$ 3.00$ \\
\hline 9 & Becerra & de dos años, prieta & $\$ 2.00$ \\
\hline 10 & Becerro & de un ańo, pinto de hosco & $\$ 1.50$ \\
\hline 11 & Becerra & zorrilla de un año & $\$ 10.00$ \\
\hline 12 & Burra & tordilla & $\$ 3.30$ \\
\hline 13 & Burra & mojina, chaparra & $\$ 3.00$ \\
\hline 14 & Burra & prieta, delgadita & $\$ 3.30$ \\
\hline 15 & Burra & parda plomo, con cría & $\$ 2.00$ \\
\hline 16 & Burra & bruta, mojina de tres años & $\$ 2.00$ \\
\hline 17 & Puerco & pinto grande & $\$ 0.50$ \\
\hline 18 & Puerca & prieta golondrina & $\$ 0.50$ \\
\hline 19 & Puerca & pinta & $\$ 0.40$ \\
\hline 20 & Puerca & bermeja & $\$ 0.30$ \\
\hline 21 & Puerco & pinto, añejo, entero & $\$ 0.20$ \\
\hline 22 & Puerca & pinta, añeja & $\$ 0.20$ \\
\hline 23 & Puerco & pinto, novillo & $\$ 0.20$ \\
\hline 24 & Puerca & prieta, oreja mocha & $\$ 0.10$ \\
\hline 25 & Puerco & chico, bolita & $\$ 0.10$ \\
\hline 26 & Puerca & chica, cinchada & $\$ 0.10$ \\
\hline 27 & Puerco & chico, mano blanca & $\$ 0.10$ \\
\hline 28 & Puerco & pinto, manchado & $\$ 0.10$ \\
\hline \multirow[t]{2}{*}{29} & Puerco & chico, el ratón & $\$ 0.10$ \\
\hline & & & $\$ 78.00$ \\
\hline
\end{tabular}


Cuadro i. Animales y Aperos

Micaela García (continuación)

\begin{tabular}{cllc}
\hline \multicolumn{4}{c}{1907} \\
\hline Núm. & Aperos & Descripción & Valor \\
\hline 1 & Aparejo & de la burra grande, con todo avío & $\$ 2.00$ \\
2 & Aparejo & $\begin{array}{l}\text { de la burra chaparra, con todo avío menos } \\
\text { cincha }\end{array}$ & $\$ 1.50$ \\
3 & Aparejo & de la burra delgadita, con todo avío & $\$ 2.00$ \\
4 & Aparejo & de la burra parda plomo con avío & $\$ 0.50$ \\
5 & Albardon & nuevo, con freno nomás & $\$ 0.50$ \\
6 & Silloncito viejo, con cincho & $\$ 0.15$ \\
& & & Tran Total \\
& & $\$ 84.65$ \\
\hline
\end{tabular}

Fuente: Testamento de dońa Micaela García.

edad de los animales eso, al parecer, no influía en el precio. No se mencionaron en el testamento especies menores, como las gallinas -que había en todos los hogares-como rubros heredables.

Los aperos -aparejos, albardón y silloncito-dan cuenta de la importancia de los animales para trabajar y para desplazarse. Dońa Micaela conservó hasta su muerte su "caballo de silla o manso" y un albardón "nuevo con freno". Los "Bienes y enseres de casa" -que incluían muebles, enseres de la casa y la cocina y las imágenes- representaban el tercer activo más importante de dońa Micaela: $\$ 23.82$ (cuadro 2). Lo más valioso era su máquina de coser con "todo avío" - \$6.50-, lo que reitera lo que se recuerda hasta la fecha: que si no toda, al menos la mayor parte de la ropa y todo lo que requería ser confeccionado en un hogar era hecho por las mujeres de la casa. Doña Micaela le heredó esa máquina de coser a su hija María del Refugio, que estaba recién casada.

Llama la atención la cantidad y variedad de imágenes sagradas que tenía y que eran de amplia y arraigada devoción en Jalisco en ese tiempo: San Luis Gonzaga, Nuestra Señora de Talpa, San Francisco de Paula, Nuestra Señora de los Dolores, San José y Nuestra Señora del Refugio. Llama la atención que no hubiera imágenes del Señor 
Cuadro 2. Otros bienes y enseres de casa Micaela García

\begin{tabular}{|c|c|c|}
\hline \multicolumn{3}{|c|}{1907} \\
\hline \multicolumn{3}{|c|}{ Muebles } \\
\hline Articulo & Descripción & Valor \\
\hline Máquina de coser & con todo avío & $\$ 6.50$ \\
\hline una petaquilla & - & $\$ 1.00$ \\
\hline una caja & vieja & $\$ 0.34$ \\
\hline una mesa & chica & $\$ 0.50$ \\
\hline una mesa & grande & $\$ 0.37$ \\
\hline burro del agua & de la sala & $\$ 0.25$ \\
\hline gotera & chica de pino & $\$ 0.20$ \\
\hline gotera & grande de pino & $\$ 0.10$ \\
\hline un armazón de cama & con dos banquillos y tres tablas & $\$ 0.50$ \\
\hline un tercio tablitas & de 8 piezas & $\$ 0.25$ \\
\hline una silla & grande de pino de asiento & $\$ 0.08$ \\
\hline una silla & chica de pino de asiento & $\$ 0.08$ \\
\hline dos sillas & de asiento de tule & $\$ 0.20$ \\
\hline un clavijero & - & $\$ 0.08$ \\
\hline una papelera & - & $\$ 0.10$ \\
\hline \multirow[t]{2}{*}{ Total } & & $\$ 10.55$ \\
\hline & Enseres de la casa & \\
\hline colchón & solo, ni sábana & $\$ 1.50$ \\
\hline un cobertor & - & $\$ 1.16$ \\
\hline una cobija & rallada & $\$ 0.50$ \\
\hline piedra & de ojo & $\$ 0.06$ \\
\hline un baulito & con chapa & $\$ 0.08$ \\
\hline un libro & de la valle & $\$ 0.16$ \\
\hline un libro & vecita diaria con un pano & $\$ 0.12$ \\
\hline una plancha & grande & $\$ 0.25$ \\
\hline una plancha & chica & $\$ 0.20$ \\
\hline 3 costales & dos de yute y uno de raspa & $\$ 0.32$ \\
\hline una baquetilla & puerco & $\$ 0.25$ \\
\hline una jarcia & con barzón & $\$ 0.50$ \\
\hline una jarcia & sin barzón & $\$ 0.37$ \\
\hline
\end{tabular}


Cuadro 2. Otros bienes y enseres de casa Micaela García (continuación)

\begin{tabular}{|c|c|c|}
\hline \multicolumn{3}{|c|}{1907} \\
\hline una jarcia & vieja & $\$ 0.12$ \\
\hline un garnil & de ixtle y una regla de pino larga & $\$ 0.10$ \\
\hline 2 cazos & viejos & $\$ 2.66$ \\
\hline un petacón & de petate y una pila de piedra & $\$ 0.16$ \\
\hline un sagalejo & de balleta & $\$ 0.75$ \\
\hline una almohada & de lana & $\$ 0.25$ \\
\hline una servilleta & de manta, grande num & $\$ 0.10$ \\
\hline dos servilletas & chica & $\$ 0.13$ \\
\hline cuatro servilletas & - & $\$ 0.07$ \\
\hline unas tijeras & nuevas & $\$ 0.12$ \\
\hline 2 canoas & de roble y unas tijeras viejas & $\$ 0.15$ \\
\hline \multirow[t]{2}{*}{ una gorra } & fina, viejita, con su paño de envoltura & $\$ 0.38$ \\
\hline & Total & $\$ 10.46$ \\
\hline & Cocina & \\
\hline 4 platones & talavera & $\$ 0.32$ \\
\hline un platoncito & china & $\$ 0.20$ \\
\hline 4 porcelanas & china & $\$ 0.80$ \\
\hline 2 tazas & talavera, sin oreja & $\$ 0.12$ \\
\hline 3 tazas & con oreja y dos con oreja mocha & $\$ 0.12$ \\
\hline un platón & talavera, tapado & $\$ 0.03$ \\
\hline un vaso & cristal & $\$ 0.12$ \\
\hline un vaso & hojalata y un salero vidrio & $\$ 0.10$ \\
\hline una charola & hojalata una taza grande blanca & $\$ 0.10$ \\
\hline \multirow[t]{2}{*}{10 platos } & blancos y un jarro con café & $\$ 0.16$ \\
\hline & Total & $\$ 2.07$ \\
\hline \multicolumn{3}{|c|}{ Imágenes } \\
\hline 4 imágenes & juntas en vidriera & $\$ 0.16$ \\
\hline San Luis Gonzaga & - & $\$ 0.10$ \\
\hline Nuestra Señora de Talpa & y San Francisco de Paula & $\$ 0.20$ \\
\hline $\begin{array}{l}\text { Nuestra Seńora de los } \\
\text { Dolores }\end{array}$ & y Señor San José & $\$ 0.23$ \\
\hline \multirow[t]{3}{*}{ Nuestra Señora del Refugio } & & $\$ 0.05$ \\
\hline & Total & $\$ 0.74$ \\
\hline & Gran total & $\$ 23.82$ \\
\hline
\end{tabular}

Fuente: Testamento de doña Micaela García. 
de los Rayos de Temastián, la devoción microrregional más importante. Y, debía conocer bien esa devoción puesto que su hijo Francisco y sus vecinos, quizá parientes, Joaquina y Eulalio García, habían mandado a hacer exvotos de agradecimiento a esa imagen.

Había otros 32 rubros que correspondían a instrumentos de trabajo, con un valor de $\$ 10.21$, que tenían que ver con las tareas agrícolas, ganaderas y quehaceres asociados con el trabajo de la madera, algo muy usual en ese tiempo (cuadro 3). En la parroquia había abundancia y variedad de árboles, en especial, mezquites, con los cuales los grupos domésticos seguían fabricando sus instrumentos de labranza, muebles de la casa y otros aperos, como sucedía en el siglo XIX.

$\mathrm{Al}$ momento de establecer las hijuelas, es decir, la partición de la herencia, dońa Micaela procuró hacer una asignación de valor y distribución increíblemente igualitaria en términos monetarios; cálculo hecho con gran cuidado: a cada uno de sus hijos le correspondieron entre $\$ 20.41$ y $\$ 20.69$ (cuadros 4 a 9). En cada hijuela había dos rubros especialmente valiosos que correspondían a algún animal, por lo regular, vacuno (vaca con cría, buey, en menor medida, burros) y algún otro artículo o instrumento que sumara alrededor de \$10.00: la máquina de coser, el albardón, la carreta. Lo demás eran los diferentes enseres e instrumentos de trabajo de la casa.

No se advierte la intención de dotar a algún hijo o hija de algo específico, sino de equilibrar totales que resultaran equivalentes en términos monetarios. De cualquier manera, el que recibió más animales fue Lorenzo, quizá porque no recibió ningún objeto valioso de otra índole. Tampoco se advierte el propósito de dotar a las hijas, Guadalupe y María del Refugio, de determinadas especies. Guadalupe recibió sobre todo ganado vacuno - una vaca cargada, una becerra y un buey- y una puerca; en tanto su hermana, María del Refugio, heredó una vaca con cría, dos puercos y dos puercas.

A Lorenzo, su hijo menor, le dejó el cobro de dos deudas: una de veinte centavos con $\mathrm{N}$, que podría ser su hermano Nicolás, y otra de diez centavos con Victoriano, ese sí, con seguridad, uno de sus hermanos mayores. Doña Micaela le dejó de herencia a Nicolás, el hijo con el que vivió hasta su muerte, un garnil, es decir, una bolsa don- 
Cuadro 3. Instrumentos de trabajo Micaela García

\begin{tabular}{|c|c|c|}
\hline \multicolumn{3}{|c|}{1907} \\
\hline Artículo & Descripción & Valor \\
\hline Arteza & mantequera & $\$ 0.18$ \\
\hline Arteza & grande & $\$ 0.10$ \\
\hline Burro & pino para las sillas & $\$ 0.15$ \\
\hline Máquina & de torcer & $\$ 0.30$ \\
\hline Cabrilla & - & $\$ 0.05$ \\
\hline Carreta & con yugo, anillo y cuarta & $\$ 4.04$ \\
\hline Medio decálitro & - & $\$ 0.25$ \\
\hline Doble litro & - & $\$ 0.10$ \\
\hline Doble litro & - & $\$$ \\
\hline Cuarterón & - & $\$ 0.06$ \\
\hline Barra de fierro & - & $\$ 0.50$ \\
\hline Talache & - & $\$ 0.50$ \\
\hline Pala & de fierro, nueva & $\$ 0.30$ \\
\hline Pala & de fierro, vieja & $\$ 0.15$ \\
\hline Azadón & grande, cabo palo colorado & $\$ 0.25$ \\
\hline Azadón & grande, cabo frijolillo & $\$ 0.18$ \\
\hline Azadón & grande & $\$ 0.30$ \\
\hline Reja & manos grandes & $\$ 0.34$ \\
\hline Reja & manos curras & $\$ 0.30$ \\
\hline Reja & herrada & $\$ 0.20$ \\
\hline Reja & mano quebrada & $\$ 0.18$ \\
\hline Azuela carpintera & - & $\$ 0.37$ \\
\hline Escoplo carpintero & - & $\$ 0.33$ \\
\hline Martillo & zapatero & $\$ 0.06$ \\
\hline Hoja de sierra & hechiza & $\$ 0.04$ \\
\hline Hoja de serrucho & - & $\$ 0.05$ \\
\hline Fierro de herrar & - & $\$ 0.06$ \\
\hline Broca torsal & - & $\$ 0.06$ \\
\hline Triángulo & y una rosadera & $\$ 0.03$ \\
\hline Picadera & - & $\$ 0.25$ \\
\hline Hacha carpintera & - & $\$ 0.50$ \\
\hline & Total & $\$ 10.21$ \\
\hline
\end{tabular}

Fuente: Testamento de dońa Micaela García. 
Cuadro 4. Hijuela de Francisco Valdés García

\begin{tabular}{lll}
\hline \multicolumn{2}{c}{1907} & \\
\hline & \multicolumn{2}{c}{ Valor } \\
\hline 1 vaca & horra o cargada & $\$ 7.00$ \\
1 torete & de dos ańos, barroso amarillo & $\$ 3.00$ \\
1 albardón & nuevo con fierro nomás & $\$ 5.00$ \\
1 aparejo & de la burra grande, con todo avío & $\$ 2.00$ \\
1 puerco & pinto grande & $\$ 0.50$ \\
5 platones & 4 platones talavera y un platoncito china & $\$ 0.62$ \\
1 picadora & un martillo zapatero y una picadera & $\$ 0.31$ \\
1 vaso & cristal & $\$ 0.12$ \\
1 sillón & viejo con cincho & $\$ 1.50$ \\
1 puerca & pinta & $\$ 0.43$ \\
& & Total \\
\hline
\end{tabular}

Fuente: Testamento de dońa Micaela García.

Cuadro 5. Hijuela de Guadalupe Valdés García

\begin{tabular}{llc}
\hline & \multicolumn{2}{c}{1907} \\
\hline 1 vaca & zorrilla & Valor \\
1 becerra & zorrilla de año & $\$ 7.00$ \\
1 buey & pinto grande, hosco & $\$ 1.00$ \\
1 cazo & viejo & $\$ 8.00$ \\
1 puerca & prieta golondrina & $\$ 1.33$ \\
1 cobertor & - & $\$ 0.50$ \\
1 sagalejo & balleta & $\$ 1.16$ \\
2 tazas & talavera sin oreja & $\$ 0.75$ \\
1 libro & de la recita diario & $\$ 0.12$ \\
1 tijeras & nuevas & $\$ 0.12$ \\
1 servilleta & manta, grande & $\$ 0.12$ \\
1 silla & asiento de tule & $\$ 0.10$ \\
1 arteza & grande y un baulito con chapa & $\$ 0.10$ \\
& & $\$ 0.18$ \\
& & $\$ 20.48$ \\
\hline
\end{tabular}

Fuente: Testamento de dońa Micaela García. 
Cuadro 6. Hijuela de Victoriano Valdés García

\begin{tabular}{llr}
\hline \multicolumn{2}{c}{1907} & \\
\hline & \multicolumn{2}{c}{ Valor } \\
\hline 1 baquilla & gruperilla & $\$ 7.00$ \\
1 becerra & de dos años, prieta & $\$ 2.00$ \\
1 burra & mojina, chaparra & $\$ 3.00$ \\
1 aparejo & de la burra chaparra, con todo avío, menos cincha & $\$ 1.50$ \\
1 talache & - & $\$ 0.50$ \\
1 pala & fierro nueva & $\$ 0.37$ \\
1 reja & manos grandes & $\$ 0.37$ \\
1 burro & pino, para las sillas & $\$ 0.15$ \\
1 carreta & con yugo, anillo y cuarta & $\$ 4.00$ \\
1 libro & de la Valle & $\$ 0.16$ \\
1 cuarterón & y una gotera grande de pino & $\$ 0.16$ \\
3 tazas & una con oreja y 2 mochas; una broca torsal & $\$ 0.18$ \\
1 arteza & mantequera y Nuestra Seńora de Talpa y San & $\$ 0.38$ \\
& Francisco & \\
1 petacón & y una pila de piedra, 4 imágenes juntas en vidriera & $\$ 0.32$ \\
1 jarcia & con barzón & $\$ 0.50$ \\
& & $\$ 20.59$ \\
\hline
\end{tabular}

Fuente: Testamento de doña Micaela García.

Cuadro 7. Hijuela de Nicolás Valdés García

\begin{tabular}{llr}
\hline & \multicolumn{2}{c}{1907} \\
\hline 1 buey & grande pinto de negro & Valor \\
1 burra & bruta mojina, de 3 años & $\$ 10.00$ \\
1 burra & prieta delgadita & $\$ 3.00$ \\
1 aparejo & de la burra delgadita con todo avío & $\$ 2.00$ \\
1 hacha & carpintera & $\$ 0.50$ \\
1 burro & del agua de la sala & $\$ 0.25$ \\
1 azadón & grande, cabo palo colorado & $\$ 0.25$ \\
4 costales & de yute y uno de raspa & $\$ 0.32$ \\
1 medio decá- & - & $\$ 0.25$ \\
litro & & $\$ 0.10$
\end{tabular}


Cuadro 7. Hijuela de Nicolás Valdés García (continuación)

\begin{tabular}{lll}
\hline \multicolumn{2}{c}{1907} & \\
\hline & \multicolumn{2}{c}{ Valor } \\
\hline 2 servilletas & - & $\$ 0.13$ \\
1 garnil & 1 regla de pino larga & $\$ 0.10$ \\
1 rosadera & y un triángulo & $\$ 0.06$ \\
1 escoplo & carpintero y 10 platos y jarro con café & $\$ 0.53$ \\
1 aparejo & $\begin{array}{l}\text { de la burra parda plomo con avío; una máquina } \\
\text { de torcer }\end{array}$ & $\$ 0.87$ \\
& & Total \\
\hline
\end{tabular}

Fuente: Testamento de dońa Micaela García.

Cuadro 8. Hijuela de Refugio Valdés García

\begin{tabular}{lll}
\hline & \multicolumn{1}{c}{1907} & \\
\hline & \multicolumn{2}{c}{ Valor } \\
\hline 1 vaca & chueca de añejo con cría & $\$ 6.00$ \\
1 maquina & de coser con todo avío & $\$ 6.50$ \\
1 cazo & viejo & $\$ 1.33$ \\
2 planchas & una grande y una chica & $\$ 0.45$ \\
1 colchon & solo, ni sábana & $\$ 1.50$ \\
1 caja & vieja & $\$ 0.37$ \\
1 azadón & grande cabo frijolillo & $\$ 0.18$ \\
1 pala & fierro, vieja & $\$ 0.15$ \\
1 puerco & pinto, novillo & $\$ 0.20$ \\
1 litro & doble litro & $\$ 0.08$ \\
1 reja & una barra fierro y reja manos curras & $\$ 0.80$ \\
1 imagen & de Nuestra Señora de los Dolores y San José & $\$ 0.23$ \\
1 serrucho & una hoja de serrucho, 4 porcelanas chinas y 1 & $\$ 0.88$ \\
1 gorrita & platón talavera tapado & \\
& fina, viejita con su paño de envoltura y una & $\$ 0.70$ \\
1 puerco & puerca bermeja & chico bolita, un clavijero \\
1 puerca & chica cinchada, una papelera & $\$ 0.18$ \\
1 almohada & lana, una jarcia sin barzón & $\$ 0.18$ \\
1 jarcia & sin barzón & $\$ 0.62$ \\
& & $\$ 0.12$ \\
\hline
\end{tabular}

Fuente: Testamento de doña Micaela García. 
Cuadro 9. Hijuela de Lorenzo Valdés García

\begin{tabular}{|c|c|c|}
\hline \multicolumn{3}{|c|}{1907} \\
\hline & & Valor \\
\hline 1 vaca & horra o cargada & $\$ 7.00$ \\
\hline 1 becerro & de año, pinto de horco & $\$ 1.50$ \\
\hline 1 burra & tordilla & $\$ 3.33$ \\
\hline 1 azuela & carpintera & $\$ 0.37$ \\
\hline 1 mesa & chica & $\$ 0.50$ \\
\hline 1 petaquilla & - & $\$ 1.00$ \\
\hline 1 asadon & grande & $\$ 0.33$ \\
\hline 2 puercos & uno pinto añejo, entero y una puera pinta añeja & $\$ 0.45$ \\
\hline 1 gotera & chica, pino & $\$ 0.20$ \\
\hline 1 silla & grande de pino de asiento y 4 servilletas & $\$ 0.15$ \\
\hline 1 baquetilla & de puerco y una cobija rallada & $\$ 0.75$ \\
\hline $\begin{array}{l}1 \text { San Luis } \\
\text { Gonzaga }\end{array}$ & una charola hojalata, una taza grande blanca & $\$ 0.20$ \\
\hline 1 reja & herrada de hojalata y un vaso y un salero de vidrio & $\$ 0.35$ \\
\hline 1 imagen & $\begin{array}{l}\text { de Nuestra Señora de Refugio y } 20 \text { centavos en } \\
\text { deuda con N. }\end{array}$ & $\$ 0.25$ \\
\hline 1 cabrilla & y una piedra de ojo & $\$ 0.14$ \\
\hline 2 canoas & $\begin{array}{l}\text { de roble, unas tijeras viejas y } 10 \text { centavos en } \\
\text { droga con Victoriano }\end{array}$ & $\$ 0.25$ \\
\hline 1 burra & $\begin{array}{l}\text { parda plomo con cría, una reja, un armazón de } \\
\text { cama con dos banquillos y tres tablas }\end{array}$ & $\$ 2.58$ \\
\hline 1 mesa & $\begin{array}{l}\text { grande, un tercio tablas y } 1 / 3 \text { de tablitas de } \\
\text { ocho piezas, } 1 \text { silla chica de pino de asiento }\end{array}$ & $\$ 0.85$ \\
\hline 1 puerca & prieta, oreja mocha & \\
\hline 3 cochinos & $\begin{array}{l}\text { uno de mano blanca, pinto manchado y uno } \\
\text { chico el ratón. Una hoja de sierra hechiza }\end{array}$ & $\$ 0.21$ \\
\hline & & $\$ 20.41$ \\
\hline
\end{tabular}

Fuente: Testamento de dońa Micaela García.

de se guardaba la pólvora. Eso hace suponer que ella tenía armas, pero si las había, éstas no se registraron en el testamento, ni en el inventario, ni en las hijuelas.

Así las cosas, cada uno de los hijos de doña Micaela recibió una herencia, en efectivo y en especie, de alrededor de \$54.00. El que recibió un poco más en especie fue Nicolás, aunque fue el que obtu- 
vo menos animales. Lo que no se sabe es qué norma había -si la había- o qué sucedía con el dinero en efectivo que recibían los y las herederos. De cualquier manera, una suma así le puede haber permitido a cada uno comprar, por lo menos, varios animales.

\section{EN I920}

Había 256 personas en El Bajío, asentamiento que en ese momento fue denominado Bajío de Sánchez. En ese momento, había 60 hogares, que seguían siendo muy variados en su composición. De cualquier modo, los hogares más frecuentes seguían siendo los nucleares -19-y, en segundo lugar, los encabezados por las madres viudas y sus hijos -6-. Los hogares que más habían aumentado después de la Revolución eran los de personas solas -9-.

A pesar de las dificultades y peripecias de los años transcurridos entre 1905 y 1920 los seis hermanos Valdés García habían sobrevivido y vivían en El Bajío. Pero, claro, se habían suscitado muchos cambios en sus vidas. Francisco, el mayor, que declaró tener 53 años, seguía siendo labrador, y había enviudado, un año antes, en 1919. Entre 1905 y 1920 habían muerto siendo niños dos de sus hijos: Hilaria y Mucio (Pinedo Valdés, s.f.). Ellos no fueron registrados en ninguno de los dos padrones.

En 1920, Francisco vivía con tres hijos: Nicolás, de 13 años; Cándido de 9 y Emilia de 7. Ángel, que en 1905 fue registrado de un día de nacido, no apareció mencionado en 1920, porque 3 años antes, en 1917, había ingresado al Seminario de Nuestra Seńora de Guadalupe en Totatiche para iniciar su carrera sacerdotal. Francisco, al enviudar, llevó a su hija Emilia a vivir con unos parientes acomodados de Totatiche (Pinedo Valdés, s.f.). Su hijo Nicolás también optó por la carrera sacerdotal y se convirtió además en un reconocido historiador de la Cristiada en la región Norte de Jalisco (Pinedo Valdés, s.f.). El menor, Cándido, murió en 1926, a los 16 años, en Jalpa, Zacatecas, durante la Guerra Cristera.

En 1925, después de 6 años de viudez y 63 años, Francisco se casó en segundas nupcias con Anselma Rojas, soltera de 35 años, vecina del mismo rancho, pero de esa unión ya no hubo descen- 
dientes (Pinedo Valdés, s.f.). Francisco, que era muy católico, murió ahorcado por los federales en 1928 (Pinedo Valdés, s.f.).

María Guadalupe, de 48 años, seguía en calidad de viuda, y vivía con sus dos hijos menores: Aleja, de 23 años, que estaba soltera, e Hildefonso, de 17 ańos, labrador y también soltero. Ya no vivían con ella sus hijos mayores: Jorge y Rafael Huerta. Los dos habían migrado a El Salitre, donde eran comerciantes. El Salitre estaba a punto de convertirse en la cabecera municipal de lo que sería el municipio de Villa Guerrero, donde vivían 1,017 personas, es decir, que era una localidad más poblada como para dedicarse al comercio, que el Bajío, donde se había quedado su madre. En El Salitre había 20 personas de apellido Huerta lo que permite suponer que Jorge y Rafael tenían parientes en esa población por parte de su padre. Jorge tenía 28 años, estaba casado con Estefana Solís, de 26 años y no tenían hijos. Rafael tenía 25 ańos, estaba casado con Teodora Bedoy, de 25 años y tenían un hijo, Anselmo, de un año.

Victoriano, que dijo tener 48 años (de acuerdo con el Padrón de 1905 tendría 44), seguía casado con Josefa Haro, de 36 años. Tenían seis hijos: Manuel, de 15 ańos; Elena, de 13; una hija sin nombre (quizás se llamaba Tita), de 10; Ausencio, de 8; Otigina de 5 y Pilar de un año. Seguramente, Manuel ya le ayudaba a su padre en las labores del campo.

Lorenzo, labrador, de 39 años (tendría 37 según el Padrón de 1905) seguía casado con María Refugio Ramos, de 30 años, y tenían siete hijos: Jesús, de 12 años; Aurora, de 10; Andrea, de 8; Juana, de 6; María Auxilio, de 4; María Piedad, de 2 y Salvador, de un año. Jesús quizá ya le ayudaba a su padre.

María del Refugio, la cuata o gemela de Lorenzo, de 39 años, había enviudado de su esposo Francisco González, y vivía con dos hijos pequeños que poco podían ayudarla: Hilaria, de 12 años y Francisco, de 10 años. En esa situación, María del Refugio había sido recogida por su hermano don Francisco (Pinedo Valdés, s.f.).

Nicolás, fue el último en casarse, dos años después de la muerte de su madre. Lo hizo en 1909, a los 30 años con Cesárea Díaz, de 19 años, vecina de la localidad de Sataray, como su cuñada -María del Refugio Ramos- que estaba casada con su hermano Lorenzo. En 
1920, Nicolás, de 42 años, era labrador, vivía con Cesárea Díaz, pero no tenían hijos y, al parecer, de ese matrimonio no hubo descendencia (A.P., comunicación personal).

¿Cuántos años más vivieron los hermanos Valdés García? Salvo el caso de Francisco, que murió en 1928 de muerte violenta, no lo sabemos, pero dada la esperanza de vida en esos años, todos estaban ya en el ocaso de sus trayectorias.

\section{EN SÍNTESIS}

El documento testamentario de doña Micaela García permite pensar que en Totatiche se habían construido normas respecto a la herencia que no excluían a las mujeres como sucedía en las sociedades indígena y campesina. Las mujeres eran sujeto de herencia de tierras, casas, animales y enseres que, a su vez, podían heredar a sus hijos e hijas. En el testamento quedó muy claro que sus hijos e hijas podían vender su parte sin autorización de sus cónyuges porque se trataba, justamente, de una herencia. En el caso de dońa Micaela lo más probable es que el rancho hubiera sido heredado por ella, ya que colindaba con una propiedad de su hermano y otros parientes.

Quizá no era una situación generalizada, en tanto se trataba de una sociedad muy pobre, donde la mayor parte de la población carecía de bienes heredables, pero en caso de haberlos, las mujeres podían ser herederas. Y esta posibilidad debe haber estado socialmente reconocida ya que, ante la ausencia de documentos que avalaran la propiedad, la transmisión de bienes requería de un alto nivel de consenso entre la población. Es decir, que la sociedad reconociera la legitimidad de los bienes de las mujeres.

Es difícil saber cómo y cuándo se había llegado a esa situación en una sociedad tan pobre y aislada como era la microrregión de Totatiche. Tampoco es posible establecer qué tanto pesaban en los acuerdos locales lo que sucedía en otros lugares. La tradición oral, sin poder precisar fechas, da cuenta de un sistema de herencia bilateral que incluía a las mujeres. La explicación permanece como hipótesis. La inclusión de las mujeres como herederas podría tener que ver con la escasez de los recursos económicos y la fragilidad de los hogares 
debido a una situación demográfica muy vulnerable. En la parroquia, si tomamos sólo los años de adultez, a partir de catorce ańos para hombres y mujeres, el promedio de edad de los hombres al morir era de 52 años y de 46 años en el caso de las mujeres (Arias 2014). Así las cosas, muchas parejas enviudaban, en especial, las mujeres. Y más mujeres que hombres permanecían en esa condición por el resto de sus vidas. La viudez formaba parte del escenario previsible de la vida de hombres y mujeres. En 1905 había 610 viudos, de los cuales 412 eran mujeres y 198 eran hombres. En 1920 había 926 personas en esa situación, la mayor parte de las cuales -667eran mujeres y 259 eran hombres (Arias 2014).

¿Qué hubiera pasado en el hogar de dońa Micaela si ella, viuda a las 34 años con 11 hijos, que se fueron muriendo hasta quedar sólo seis, no hubiera tenido el rancho para trabajarlo y vivir de él con ayuda de sus hijos? El destino de esos hogares era ampliamente conocido. La viudez femenina sin propiedad llevaba a sus hogares a la extrema pobreza, al jornalerismo de los niños y la separación temprana con los hijos. Los hombres, a partir de los 10 años, se convertían en jornaleros que tenían que buscar el sustento para ellos, su madres y hermanos donde fuera posible; las hijas se casaban pronto para reducir la presión económica en los hogares o, si habían conseguido trabajo en la cabecera municipal, posponían el matrimonio para poder ayudar a sus madres en los ranchos. $\mathrm{O}$, bien, como fue el caso de María del Refugio, las viudas regresaban a su rancho de origen donde se acogían al apoyo de sus hermanos y parientes.

Así las cosas, quizá la viudez, que dejaba a las mujeres jóvenes, desamparadas y con varios hijos pequeños que mantener, generó la necesidad de que ellas pudieran recibir herencia de sus padres en condiciones similares a las de sus hermanos como una manera de protegerlas ante la eventualidad, nada remota, de enviudar.

De ahí quizá también la vigencia de la equidad como principio hereditario. Y esto por encima de consideraciones especiales, por ejemplo, al primogénito que la había ayudado a sostener el hogar, como era el caso de Francisco; o el afecto, que apenas se manifestó en alguna preferencia hacia Nicolás, el hijo menor que permaneció soltero y vivió con ella hasta su muerte. Dońa Micaela no tuvo du- 
das ni hizo aclaraciones respecto a su decisión de heredar a sus hijos por partes iguales. Esto reitera lo que dicen los ancianos: que en Totatiche la herencia de tierras y otros bienes era igualitaria, es decir, que las mujeres y los hombres eran herederos de sus padres en las mismas condiciones. En eso dońa Micaela mantuvo, sin fisuras, la norma respecto a la herencia igualitaria en la microrregión. Lo que las mujeres heredaban lo podían a su vez heredar de acuerdo a su voluntad. Así, el sistema de herencia predominante era bilateral e igualitario, es decir, que hombres y mujeres eran herederos de sus padres y heredaban de esa manera a sus descendientes. Pero sólo a sus hijos e hijas. En el sistema local de herencia no había, al menos a principios del siglo $\mathrm{xx}$, otros herederos colaterales o descendientes. Esto también llama la atención.

Aunque había muchos abuelos que tenían que hacerse cargo de sus nietos, su responsabilidad era criarlos, alimentarlos, vestirlos. No menos, pero tampoco más. La eventualidad de tener que criar nietos formaba parte del escenario posible en un mundo donde había mucha mortalidad de hombres y mujeres; donde los viudos, en especial, formaban nuevas uniones que podían obligar a los abuelos a acoger a los nietos de las primeras uniones de sus hijos e hijas. Pero el sistema de herencia los excluía: los nietos no se convertían en herederos. Era una manera, quizás, de evitar la fragmentación aún mayor de las propiedades y los recursos, así como de prevenir la aparición de conflictos generacionales entre padres e hijos, entre tíos y sobrinos.

La compra-venta del rancho entre familiares, como sucedió en el caso de dońa Micaela, hace pensar que persistía un viejo mecanismo detectado por Shadow (2002) que ayudaba a limitar la excesiva fragmentación de la propiedad que supone la herencia igualitaria: el derecho preferencial a la venta entre parientes. Los hijos de dońa Micaela vendieron el rancho a un tío suyo. De esa manera la propiedad de los ranchos permanecía en poder de ciertas familias a lo largo del tiempo, del paso y las contingencias de las generaciones. De ahí que se hablara, por ejemplo, de que el rancho del Bajío fuera "de los Valdés".

Pero los documentos testamentarios, aunados a las demás fuentes, permitieron reconstruir la trayectoria del grupo doméstico Valdés García, que ejemplifica dos de los rasgos característicos de la 
organización social y familiar de los grupos domésticos totatichenses a principios del siglo xx. Por una parte, una fuerte endogamia en sentido estricto, es decir, por lazos de parentesco y también por endogamia residencial. Los dos hijos mayores de doña Micaela, Francisco y Guadalupe, se casaron con personas del mismo apellido que eran vecinos de El Bajío, que también podrían ser parientes. En cualquier caso, con su matrimonio habían emparentado.

Los otros cuatro hijos de dońa Micaela rompieron con la endogamia residencial al casarse con personas de otras tres localidades, pero todas cercanas y de la misma parroquia: Tlacuitapan, La Nopalera y Sataray. Tres de los hombres se casaron de ese modo y llevaron a sus cónyuges a vivir a El Bajío, lo que reitera que la tendencia predominante era la llegada de mujeres a los ranchos por vía del matrimonio. La residencia era claramente patrilineal, pero también neolocal. Se trataba de grupos domésticos emparentados, pero que no compartían cuartos ni cocina. Lo que sí sucedía era que vivían cerca unos de otros. En el caso de doña Micaela, ella vivía con sus hijos, rodeada de vecinos de apellidos Valdés y García, parientes de ella o de su esposo.

Aunque en la parroquia y el rancho predominaban los hogares nucleares, el segundo tipo de hogar era el formado por un padre o madre viudos, como el de dońa Micaela. La viudez acontecía en cualquier momento, a cualquier edad en la vida de los hombres y de las mujeres. Pero había diferencias.

Como muestra el ejemplo de la familia Valdés García, las tres mujeres -doña Micaela y sus dos hijas, Guadalupe y María del Refugio-, quedaron viudas antes de cumplir 40 ańos y, sin proveedores masculinos, tuvieron que hacerse cargo de hijos e hijas, que desde pequeńos participaron en las tareas del campo y ayudaron a conseguir los recursos para la sobrevivencia del grupo doméstico. Tener un rancho y casa propios le ayudó sin duda a doña Micaela a sobrellevar una viudez con once, más tarde, seis hijos a los que con ayuda de Francisco, su hijo mayor, crió hasta que se casaron; al final de sus días, les heredó a todos el rancho, que muy pronto vendieron, además de animales, instrumentos de trabajo y artefactos que les deben haber servido para vivir mejor. 
No sabemos, en cambio, la situación económica en que quedó Guadalupe, pero de cualquier manera lo heredado pudo haberle sido de ayuda, así como el permanecer cerca de sus hermanos, como fue el caso de ambas durante su viudez. En el caso de María del Refugio su vida al parecer se precarizó al enviudar: ella, al casarse, debe haberse ido a vivir al rancho de su esposo, La Nopalera, pero regresó a El Bajío, donde vivían sus hermanos y tuvo que ser acogida en el hogar de su hermano Francisco.

Las mujeres de esa familia se casaron entre los 14 y los 23 ańos; lo que era usual entre las mujeres de la parroquia. Las que se convirtieron en viudas, permanecieron como tales. Los hombres se casaron de más edad que las mujeres, a partir de 24 años, en el caso de los Valdés García. Incluso muy mayores: Francisco se casó de 36 años y Nicolás de 30, después de la muerte de su madre.

Los hombres cuando quedaban viudos no solían permanecer como tales. Francisco, el hijo mayor de doña Micaela, duró 6 años viudo, pero finalmente, de más de 60 años, se volvió a casar. El siempre había criticado a los que lo hacían y decía que "ahora la gente tenía el cuchillo y que él era la carne" (Pinedo Valdés, s.f.). Y es que para los hombres no había límite de edad para uniones consecutivas, como sucedía en el caso de las mujeres. Los viudos solían establecer una segunda unión, con mujeres, muchas veces solteras y bastante más jóvenes que ellos, como fue el caso de Francisco. Ese parecería ser el caso, también, de Francisco García, el hermano y comprador del rancho de doña Micaela, que había formado lo que parece haber sido una segunda unión con una mujer 13 años más joven que él, con la que tenía un hijo de 17 años. En situaciones como esa, los hijos de la primera unión tendían a salir muy pronto del hogar paterno. En el caso de Francisco García uno de los hijos de su primera unión, Pablo, había permanecido cerca del padre. Ayudar al padre, pero también la posibilidad de heredar pueden haber sido motivos poderosos de esa decisión de Pablo.

El testamento de dońa Micaela muestra, finalmente, que en ese hogar no existía una especialización económica ni por sexo. Sus hijos e hijas se dedicaban a las actividades agropecuarias: producción agrícola; a la cría, engorda y venta de ganado; hacían quesos; cazaban; se 
encargaban de los trabajos que requerían la agricultura y la ganadería. Aunque el grupo doméstico de dońa Micaela era más acomodado que muchos en El Bajío y en Totatiche, en términos de organización social era como muchos otros de la parroquia en ese tiempo.

\section{Archivos}

Censo de la Parroquia de Totatiche mandado formar por el Ilmo. y Rmo. Señor Arzobispo de Guadalajara, Dr. y Mtro. D. Francisco Orozco y Jiménez, siendo párroco interino el Pbro. Cristóbal Magallanes. Totatiche, mayo de 1920. Sin numeración.

Padrón de la feligresía de la Parroquia de Totatiche, mandado formar por el Cura propio Regino Ramos Pedroza el año de 1905. E. Rubalcaba. Notario. 1-155 vuelta.

\section{BibLIOGRAFÍA}

Arias, Patricia, Retrato escrito. Los grupos domésticos y el espacio en Totatiche, Jalisco. 1905-1920, Guadalajara, El Colegio de Jalisco, 2014.

,"El mundo de los amores imposibles. Residencia y herencia en la sociedad ranchera", en David Robichaux, comp., Familiay parentesco en México y Mesoamérica. Unas miradas antropológicas, México, Universidad Iberoamericana, 2005, 123-159.

BÁrCena, Mariano, Ensayo estadístico del Estado de Jalisco, Guadalajara, Secretaría General de Gobierno, unEd, 1983.

Bracamonte y Sosa, Pedro y Gabriela Solís, Espacios mayas de autonomía. El pacto colonial en Yucatán, Mérida, Universidad Autónoma de Yucatán, Conacyt, 1996.

Calvo, Thomas, "Un testamento zacatecano de 1550", en Thomas Calvo, La Nueva Galicia en los siglos XVI y XVII, Guadalajara, El Colegio de Jalisco, CEMca, 1989, 95-102.

Carrasco, Pedro y Jesús Morjarás-Ruiz, Colección de documentos sobre Coyoacán, México, Ciesas, 1978.

Cline, Sarah, "The Testament of Culhuacan”, Disponible en Google Académico, University of Oregon, 7 de agosto de 2013, 2007. 
, Colonial Culhuacan, 1580-11600: A Social History of an Aztec Town, Albuquerque, University of New Mexico Press, 1986.

Cline, Sarah y Miguel León-Portilla, eds., The Testaments of Culhuacan, Los Ángeles, UCLA, Latin American Center Publications, 1984.

Deere, Carmen Diana y Magdalena León, Género, propiedad y empoderamiento: tierra, Estado y mercado en América Latina, Bogotá, TM Editores, UN, Facultad de Ciencias Humanas, 2000.

EnRíQuez, Eduardo, "Evaristo Madero E. Testamento", en Historia Mexicana, núm. 2, vol. 35, octubre-diciembre, 1985, 335-343.

Franco, Pedro, Testamento, ultima y final disposición y voluntad del Ilmo.Sr. Dr. D. Diego Rodríguez de Rivas y Velasco del Consejo de su Majestad, Obispo de Guadalajara, Guadalajara, Imprenta de don Pablo Barba, 1981.

González, Luis, "Gente del campo", en Vuelta, 151, México, 1989, 22-29.

, Pueblo en vilo, México, El Colegio de México, 1979.

GonZÁLez Montes, Soledad, "Las mujeres y las relaciones de género en las investigaciones sobre el México campesino e indígena", en Elena Urrutia, coord., Estudios sobre las mujeres y las relaciones de género en México: Aportes para desde diversas disciplinas, México, El Colegio de México, 2002, 165-200.

Gutiérrez Cham, Gerardo, "Introducción”, en José Javier Ezquerra González, Los esclavos en la Nueva Galicia: testamentos, ventas y donaciones hasta la abolición de la esclavitud, Guadalajara, Secretaría General de Gobierno, Dirección General de Archivos, 2003, 13-26.

Kellogg, Susan, Law and the Transformation of Aztec Culture. 15001700, Oklahoma, University of Oklahoma Press, 1995.

León-Portilla, Miguel, "El libro inédito de los testamentos indígenas de Culhuacán. Su significación como testimonio histórico", en Estudios de Cultura Nábualt, 12, 1976, 11-31.

Lizama Silva, Gladys, "Francisco Martínez Negrete Alba, 18481906: una biografía empresarial tapatía", en América Latina en la Historia Económica, núm. 26, julio-diciembre, 2006, 79-110. 
Martínez, Hildeberto, Tepeaca en el siglo XVI. Tenencia de la tierra y organización de un señorio, México, Ciesas, 1984.

Muriá, José María, dir., Historia de Jalisco, tomo 3, Guadalajara, Secretaría General de Gobierno, UnED, 1980.

Peniche Moreno, Paola, Ambitos del parentesco, la sociedad maya en tiempos de la colonia, México, Ciesas, Miguel Angel Porrúa, 2007.

Pinedo Valdés, José Angel, Francisco Valdés García. Testigo de Cristo. Hechos y Testimonios, Guadalajara, edición privada, s.f.

Robichaux, David, "Sistemas familiares en culturas subalternas de América Latina: una propuesta conceptual y un bosquejo preliminar" en David Robichaux, comp., Familia y diversidad en América Latina. Estudios de casos, Buenos Aires, Clacso, 2007, 27-75.

Rojas Rabiela, Teresa, Elsa Leticia Rea López y Constantino MeDINA Lima, Vidas y bienes olvidados. Testamentos indígenas novohispanos, vol. I, México, Ciesas, Conacyt, 1999a.

Vidas y bienes olvidados. Testamentos indigenas novohispanos, vol. 2. México, Ciesas, 1999b.

Tonella Trelles, María del Carmen, "Mujeres del norte. Un estudio basado en testamentos sobre la presencia femenina en Ures, Sonora”, en Región y Sociedad, núm. 21, vol. xIII, 2001, 147-193. SHADOw, Robert Dennis, Tierra, trabajo y ganado en la región norte de Jalisco, Zamora, El Colegio de Michoacán, Universidad de Guadalajara, Centro Universitario del Norte, 2002.

FECHA DE RECEPCión DEL ARTículo: 17 de junio de 2013

FECHA DE APRobación: 23 de julio de 2013

FECHA DE RECEPCIÓN DE LA VERSIÓN FINAL: 21 de agosto de 2013 